\title{
Ideology and Power in Presidential Speech
}

\author{
Meinarni Susilowati ${ }^{1, *}$ Witra Ulkhasanah ${ }^{2}$
}

\author{
${ }^{1}$ Department of English Literature, UIN Maulana Malik Ibrahim Malang, Indonesia \\ ${ }^{2}$ Department of English Literature, UIN Maulana Malik Ibrahim Malang, Indonesia \\ ${ }^{*}$ Corresponding author.Email: meinarni.susilowati@uin-malang.ac.id
}

\begin{abstract}
Despite the fact that he frequently produced controversial statements in the public domain, Donald Trump has attracted researchers' attention to investigate his political speech. His controversies may be seen as a potential area that brings linguistic currency, which may trigger ideological implications due to its condensed power. This paper aims to report how such a controversial speech served a certain degree of power that represented a particular ideology. Wodak's discursive strategies were applied to analyze 15 data derived from Trump's speech as his response to the idea of proposing Jerusalem as the capital city. The results show that nomination or referential, predication, perspectivation, argumentation and intensification strategies were applied and essentially framed within positive selfpresentation. The fact that positive self-presentation mantles ideology and power via controversial statements galvanizes propositions, strengthening the acceptance of controversy in a different fashion. Based on the findings, it is recommended to further investigate power and ideology representation, which transpires ironical expressions as positive self-representations. Such ironical expressions may conceptualize the nature of ideological power in various patterns in different contexts.
\end{abstract}

Keywords: Power, Ideology, Self-representation, political speech

\section{INTRODUCTION}

Investigating power and ideology became the focus of the researcher. The issue of recognizing Jerusalem as the capital city of Israel by Donald Trump attracted the researcher to discuss it. This study also emphasized ideology performed by the social actor as means of transforming power relations. Ideology is an important aspect of establishing and maintaining unequal power relations [1]. It means ideology and power are related to each other. Thus, ideology is a generalization of social relations; it is the ideal form of the actual relations, seen from the perspective of one position in this set of relations, but universalized, idealized and abstracted [2]. Moreover, ideology is seen as a one-sided perspective. It is composed of related mental representations, convictions, opinions, attitudes, and evaluations shared by a member of a specific social group [3]. Ideologies serve as an important means of establishing hegemonic identity narratives by controlling the access of specific discourses or public spheres.

Power is the ability to control people and events. It is about the relation of differences and the effects of differences in social structures [1]. There are some powers implemented in some ways: 'actional power' (physical force and violence), the control of people through threats and promises, an attachment to authority (the exertion of authority and submission to authority), and technical control through objects (such as means of production, means of transportation, weapons, and so on) [4].

Language is entwined in social power in several ways: language indexes power, expresses power, involved in any contention and a challenge to power [1]. Power does not derive from power, but language can be used to challenge and overthrow power and change distributions of power in the long and short term. Power is characterized not only by the grammatical forms in the text but also by a person's control over a social occasion through the text genre. Therefore, it needs CDA to answer the research problem of this study.

Critical Discourse Analysis (CDA) critically analyzes discourse to address problems of social change. CDA aims to investigate critically social 
inequality as it is expressed, signaled, constituted, legitimized, and so on by language use in discourse [1]. Discourse is a way of signifying a particular social practice domain from a particular perspective [5]. We assume a dialectical relationship between particular discursive practices and the specific fields of action (including situations, institutional frames, and social structures) in which they are embedded.

Donald Trump is a controversial politician who likes to create a problem to discriminate, especially against Muslims. His speech entitled "Recognizing Jerusalem as the capital of Israel" showed Donald Trump's controversies against what many countries have fought for. The language used in his political speech dominantly aimed at showing his power, influencing people through the ideological construction of his arguments. This topic became crucial because the recognition declared by Trump could be a historical peak. Moreover, the effect of that such a strong controversy reflected in his language might cause forever war. The Middle East conflicts were getting worse in 2017 after Donald Trump declared his decision that Jerusalem is Israel's capital.

This study was done by considering the gap from previous studies on power and ideology. First, [6] investigated power relation on Donald Trump's political campaign. The finding shows that Trump reflects his power toward people by delegitimizing other people, races, and politicians discursively through victimizing, underestimating, and discriminating others. Second, [7] investigated rhetorical devices and power relation of Hillary Clinton's and Donald Trump's statement in Presidential debate. The finding shows that Hillary Clinton's and Donald Trump used pronoun 'I', 'we', and 'us' for positive self-presentation and pronoun 'you', 'he/she' for negative self-presentation.

Furthermore, discursive power relation strategies become significant for Donald Trump and Hillary Clinton to portray their power relation by strengthening and emphasizing their argument to build ideological construction. Third, [8] examines ideology reflected from persuasive strategies in Nara Masista Rakhmania's speech at United Nations General Assembly. The results show three persuasive strategy that reflected the speaker's ideology involving repetition, analogy, and proposition.

From those previous studies, this research focuses on Donald Trump's power, which represented his ideology in his political speech. The five ways to investigate the power which represents ideology of Donald Trump were used. Based on the discussion above, this research tried to find out how power represents ideology in Donald Trump's speech on recognizing Jerusalem as Israel's capital.

\section{LITERATURE REVIEW}

\subsection{Power}

Power is someone's authority to control and influence people to do something. Power in discourse is defined as an actor's struggles over different interpretations of meaning. This struggle for semiotic hegemony relates to selecting 'specific linguistic codes, rules for interaction, rules for access to the meaningmaking forum, rules for decision-making, turn-taking, the opening of access, making contributions and interventions [10].

Power is about relations of difference and particularly about the effects of social structures' differences. When power is associated with language, "language is entwined in social power in many ways: language indexes power, expresses power, I involved where there is contention over and a challenge to power" [1]. In social relations, language and power are closely connected. Power does not derive from language, but language can be used to challenge power, subvert it, and alter power distributions in the short and long term. The language provides articulated means for differences in power in hierarchical social structures (Wodak, (2001:11). Thus, language analysis is a valuable instrument to inspect the power relation such as dominance and inequality in media discourses.

\subsection{Ideology}

Ideology is the faith or belief of someone or many people in something. Moreover, it is a system of ideas based on judgments and attitudes that aid certain forces within a society to further their interests or stabilize their power [1]. The concept of ideology is presented involving cognitive and social psychology, sociology and discourse analysis [11]. Ideology is a set of belief systems including a person's beliefs, values, goals, and anticipations.

Moreover, the cognition definition of ideology is given in terms of the social cognition shared by the group members. The social dimension explains what kind of groups; relations between groups and institutions are involved in developing and reproducing ideologies. The discourse dimension of ideologies explains how ideologies influence our daily texts and talks, understand ideological discourse, how discourse, 
and how discourse involves the reproduction of ideology in society [11].

\subsection{Critical Discourse Analysis}

This subchapter contains a brief description of Discourse Historical Approach to make the readers understand this study's theory.

\subsubsection{CDA Wodak's Discourse Historical Approach}

Discourse-Historical Approach (DHA) provides a vehicle for looking at latent power dynamics and the range of potentials in agents. It integrates and triangulates knowledge about historical sources and how discursive events are embedded in social and political fields. Moreover, the DHA distinguishes between three dimensions that constitute textual meanings and structure: the topics spoken/ written about, the discursive strategies employed, and the linguistic means drawn upon to realize both topics and strategies.

A systematic qualitative analysis in DHA takes four layers of context into account; the intertextual and interdiscursive relationships between utterances, texts, genres and discourses; the extra-linguistic social/sociological and variables; the history and archaeology of texts and organizations; and the institutional frames of the specific context of a situation.

There are five types of discursive strategies, all involved in positive self- and negative otherpresentation. Strategy generally refers to a plan of practices, including discursive practices, adopted to achieve a particular social, political, psychological or linguistic goal.

\section{A. Referential or Nomination strategies}

Social actors are constructed and represented, for example, through the creation of in- group and outgroup. This is done through a number of categorization devices, including metaphors, metonymies and synecdoches, in the form of a part for the whole or a whole standing for the part. It means that the analyst label the social actors positively or negatively, appreciatively or depreciatorily. Furthermore, identify a certain actor or collective, inferring a threat or opportunity posed by their behavior or interests.

\section{B. Predicational strategies}

Social actors as individuals, group members or group as a whole, are linguistically characterized through predications. Predicational strategies may, for example, be realized as evaluative attributions of negative and positive traits it the linguistic form of implicit or explicit predicates. These strategies aim to label social actors in a more or less positive or negative manner, and are thus closely related to nomination strategies.

C. Argumentation strategies

There are argumentation strategies and amounts of topoi through which positive and negative attributions are justified. Meanwhile, topoi are parts of argumentation that belong to an argument's obligatory premises with the conclusion or the central claim. For example, it could be suggested that the social and political inclusion or exclusion of persons or policies is legitimate. Establish the internal logic of the argument (how the issue should be dealt with) through form (topoi) and content (warrants). Topoi is defined as parts of argumentation that belong to an argument's obligatory premises, whether explicit or tacit [12]. Topoi are central to the analysis of seemingly convincing fallacious arguments widely adopted in all political debates and genres.

D. Perspectivation strategies

One may focus on the perspectivation, framing or discourse representation by means of which speakers express their involvement in discourse, and position their point of view in the repoting, description, narration or quotation of relevant events or utterances. Reinforce the speaker's legitimacy by aligning the issue at hand with: a) the speaker, b) the relevant field of action/ control and c) the discourse topic.

E. Intensification or mitigation

There are intensifying strategies in the one hand and mitigation strategies on the other. Both of these help to qualify and modify the epistemic status of a proposition by intensifying or mitigating the illocutionary force of utterances. These strategies can be an important aspect of the presentation in as much as they operate it by either sharpening it or toning it down.

\subsection{Political Speech}

Critical analysis of historical texts it is generally problematic to reconstruct the experiential correlations, using only written data associated with given linguistic conventions in a certain historical situation. This is especially true of political discourse with its power to persuade and elicit actions. In interpreting discourse one must take care not to apply present day intuitive and associative values, because of a lack of detailed knowledge of the pragmatic and psychological dimensions of a given historical situation.

Perceiving meaning means that historical linguistic data interpretation must be supported by an exact knowledge of the socio-historical context from which the historical-linguistic sources derive [1]. The various sociological, socio-psychological and linguistic 
approaches which deal critically with the analysis of ideological language use, for example, the study of the origin of myths, stereotypes, jargons, provide us with the necessary tools, which together with methods of textual analysis, enable us to analyze the meaning of political texts and to elucidate and objectify their role in historical processes.

\section{METHOD}

In this research, the constructivism paradigm is used to understand the problem, which has the resourceful source of data. Moreover, this research related to social problem and it deals with qualitative research. This research is categorized as qualitative research because it has some qualitative points; first, this research aims to understand how power represents ideology in Donald Trump speech by using CDA theory. Second, the data in this research are soft data in the forms of words and utterances. This research used CDA approach because it was the appropriate approach for analyzing the linguistic phenomena related to power and ideology in social practice. It encompassed the strategy of revealing power and ideology by labeling one region to become others' ownership.

This research's main instrument was human instrument collected and analyzed because no other instruments could do these stages of the research. The data were taken from a political speech of Donald Trump held on December 6, 2017. The original video of Donald Trump's speech was obtained from the website. Otherwise, the script was downloaded from the website entitled "Statement by President Trump on Jerusalem".

The stages of data collection cover the followings. First, download the Donald Trump speech video and the script about recognizing Jerusalem as Israel's capital. Second, watch the video to understand the speech and confirm the validity of the script. Last, watch the video several times to identify the utterances that potentially contained power and ideology.

To answer the research question, some steps have done. First, classify utterances into five discursive strategies. Every type of discursive strategies has classification. First type is nomination that contains membership categorization, metaphors, metonymies, and synecdoche. Second type is predication strategy that contains stereotypical, evaluative attribution of positive or negative traits and implicit or explicit predicates. Third type is perspectivation which contains means of reporting, description, narration or quotation of events and utterances. The forth type is argumentation strategies that contains discrimination or preferential. The last type is intensification or mitigation that contains illocutionary force (discriminatory) utterances. Then, the findings were discussed by comparing the findings to the existing theories and previous findings. The last, the conclusion was made.

\section{FINDINGS AND DISCUSSIONS}

The finding consists of data analysis based on CDA's theory of discursive strategies on power and ideology. The results of the analysis are discussed in the next section precisely in the discussion.

\subsection{Findings}

\subsubsection{Nomination strategy}

Data 1

Donald Trump promised in his 2016 election campaign to move the U.S. embassy to Jerusalem because the problem between Israel and Palestine became a pressure in Washington. However, Trump acted under a 1995 law that requires the United States to move its embassy to Jerusalem. On the other hand, the previous presidents consistently signed these waivers for more than two decades. Hence, he made a new approach to solve the problem between Israel and Palestine. He stated as follows;

"Thank you. When I came into office, I promised to look at the world's challenges with open eyes and very fresh thinking. We cannot solve our problems by making the same failed assumptions and repeating the same failed strategies of the past. Old challenges demand new approaches. My announcement today marks the beginning of a new approach to conflict between Israel and the Palestinians."

From the data above, Donald Trump stated the way he saw the problem between Israel and Palestine. He used the word 'promised' to show his power so then people would understand that he truly cared about the problem between Israel and Palestine. He also tried to influence people through his perspective that a new way or approach should solve Israel and Palestine's problem. He convinced the people by stating that old way did not give any peace to both countries. 
He influenced the people to solve the problem between Israel and Palestine, and it needs a new way or approach. He shared his perspective that could be counted as the ideology to ensure that people would agree with his announcement or recognition. Moreover, Trump used two pronouns on his statement those are, 'I' and 'We' to show himself in a positive self-presentation. People would agree with his thought that his new approach should solve the problem between Israel and Palestine. In conclusion, in this data, Trump used nomination strategies as one of five discursive strategy types as his power to represent his ideology through using those pronouns.

Data 5

Donald Trump officially recognized Jerusalem as the capital of Israel. On that day, he was proud to declare what the previous presidents have failed to be delivered. The previous President just was unable to deliver, so he was delivering.

"Therefore, I have determined that it is time to officially recognize Jerusalem as the capital of Israel. While previous presidents have made this a major campaign promise, they failed to deliver. Today, I am delivering."

Donald Trump denoted that every previous president failed to deliver the recognition just because they thought that delaying that recognition would cause the peace between Israel and Palestine. By mentioning the previous presidents, it refers to membership categorization device. According to the classification of five discursive strategies, Trump utterances included to nomination strategy because he mentioned the previous American presidents.

\subsubsection{Predication strategy}

Data 4

Donald Trump said that previous American presidents tried to delay Jerusalem's recognition as the capital of Israel. Because they believed that delaying to recognize Jerusalem would cause of peace.

"Presidents issued these waivers under the belief that delaying the recognition (PD) of Jerusalem would advance the cause of peace. Some say they lacked courage, but they made their best judgments based on facts as they understood them at the time. Nevertheless, the record is in. After more than two decades of waivers, we are no closer to a lasting peace agreement between Israel and the Palestinians. It would be folly to assume that repeating the exact same formula would now produce a different or better result."

Trump said that the previous presidents only delayed the recognition of Jerusalem as Israel's capital city. According to Trump, what previous presidents did has no better result which means the problem between Israel and Palestine haven't reach any peace yet. It has MC there which refers to Presidents. Then, there was also (PD) "delaying the recognition" which mentioned by Trump and he tried to predicate the previous presidents in negative manner. He wanted to show his power by saying the other president in a bad image. Of course, his ideology is represented by his power by revealing his opinion that repeating the same formula of solving Israel and Palestine is foolish. In other words, he wanted all people follow his direction to change the strategies of solving the problem between Israel and Palestine.

\section{Data 15}

The last data showed that Trump would ask the Vice President Pence to check and ensure that the Middle East partners to work together.

Vice President Pence will travel to the region in the coming days to reaffirm our commitment to work with partners throughout the Middle East to defeat radicalism that threatens the hopes and dreams of future generations. It is time for the many who desire peace to expel the extremists from their midst. It is time for all civilized nations, and people, to respond to disagreement with reasoned debate -- not violence.

Trump tried to defame the Middle East people by saying that it is time to expel the extremists from the midst. He tried to influence the people to believe that the extremist is coming from Palestinians itself. He also showed hi power by commanding Vice President Pence to travel the region to ensure that the moving of American Embassy would start as soon as possible. Thus, he showed his power to represent his ideology that the extremist is coming from Palestinians itself, so it's time to discriminate Palestinians. His statement is categorized as predication strategy because he stereotypes the Middle East in negative traits.

\subsubsection{Argumentation strategy}


In this data, Trump used topos of history to convince the people to agree with his decision. He tried to commend the achievement of The Middle East region. He said this region should not hold by bloodshed again.

So today, we call for calm, for moderation, and for the voices of tolerance to prevail over the purveyors of hate. Our children should inherit our love, not our conflicts. I repeat the message I delivered at the historic and extraordinary summit in Saudi Arabia earlier this year: The Middle East is a region rich with culture, spirit, and history. Its people are brilliant, proud, and diverse, vibrant and strong. But the incredible future awaiting this region is held at bay by bloodshed, ignorance, and terror.

He used the argumentation strategy which referred to topos of history. He wanted the Middle East also in the same side. So the peace agreement would be easy to achieve. He tried to influence the people especially people in the Middle East, to realize that the children should inherit the love, not the conflicts.

\subsubsection{Perspectivation strategy}

Data 7

Donald Trump delivered that Israel's right is the same as the other sovereign nation to determine its own capital. He defended Israel, but he did not defend Palestinians. It clearly, he pointed his view even it was controversial.

"Israel is a sovereign nation with the right like other sovereign nation to determine its own capital. Acknowledging this as a fact is a necessary condition for achieving peace"

Trump tried to position his point of view in the form of an argument. He expressed his involvement by saying that Israel has the right to determine its capital. This excerpt contains perspective strategy. He shows his power relation by positioning his point of view. He strengthened his point of view by saying that determining Israel's capital will achieve a feeling of peace. He also showed his power which represents his ideology for believing that Israel has the right to choose its capital city.

\section{Data 11}

In this part, President Trump revealed the preparation of moving the American embassy from Tel
Aviv to Jerusalem. It was also a form of his effort and his consistency to help to recognize Israel's capital.

That is why, consistent with the Jerusalem Embassy Act, I am also directing the State Department to begin preparation to move the American embassy from $\mathrm{Tel}$ Aviv to Jerusalem. This will immediately begin the process of hiring architects, engineers, and planners, so that a new embassy, when completed, will be a magnificent tribute to peace.

Trump was reporting how he would start the process of founding the American embassy in Jerusalem. He managed its founding by hiring architects, engineers, and planners therefore, the projects start as soon as possible. By reporting what he has done, his utterances are included into perspectivation strategy. He thought that his effort would be a magnificent tribute to peace. But actually, he did not know what would happen after finishing the American embassy's movement from Tel Aviv to Jerusalem.

\subsubsection{Intensification or Mitigation strategy}

\section{Data 12}

President Trump made the announcements very clear because facilitating the peace agreement would be great for those both sides. He said that his decision is not intended to help Israelis only but for the Palestinian too.

In making these announcements, I also want to make one point very clear: This decision is not intended, in any way, to reflect a departure from our strong commitment to facilitate a lasting peace agreement. We want an agreement that is a great deal for the Israelis and a great deal for the Palestinians. We are not taking a position of any final status issues, including the specific boundaries of the Israeli sovereignty in Jerusalem, or the resolution of contested borders. Those questions are up to the parties involved.

From the data above, it can be seen that Trump used intensification strategies because Trump tried to intensify his utterances about his decision to move the American embassy from Tel Aviv to Jerusalem by revealing his strong commitment to facilitate a lasting peace agreement. The United States wants an agreement that great for the Israelis and the Palestinians.

Data 13 
In this data, Trump stated that the United States showed his seriousness to facilitate a peace agreement for Israel and Palestinians. The, he would do everything according to his powerfulness.

The United States remains deeply committed to helping facilitate a peace agreement that is acceptable to both sides. I intend to do everything in my power to help forge such an agreement. Without question, Jerusalem is one of the most sensitive issues in those talks. The United States would support a two-state solution if agreed to by both sides.

After explaining his involvement to facilitate a peace agreement for both sides, he actually emphasized that he is a powerful president who braves to help the problem between Israel and Palestinians. In this data, Trump's statement is categorized as an intensification strategy because he intensifies himself by saying that he would do everything to help forge such an agreement.

\section{Data 15}

The last data showed that Trump would ask the Vice President Pence to check and ensure that the Middle East partners to work together.

Vice President Pence will travel to the region in the coming days to reaffirm our commitment to work with partners throughout the Middle East to defeat radicalism that threatens the hopes and dreams of future generations. It is time for the many who desire peace to expel the extremists from their midst. It is time for all civilized nations, and people, to respond to disagreement with reasoned debate -- not violence.

Trump tried to defame the Middle East people by saying that it is time to expel the extremists from the midst. It means that he tried to influence the people to believe that the extremist is coming from Palestinians itself. He also showed his power by commanding Vice President Pence to travel the region to ensure that the moving of American Embassy would start as soon as possible. Thus, he showed his power to represent his ideology that the extremist is coming from Palestinians itself, so it is time to discriminate Palestinians. His statement is categorized as a predication strategy because he stereotypes the Middle East in negative traits

\subsection{Discussion}

The findings above showed that Donald Trump often used his power relation to represent his speech ideology.
He used five types of discursive strategies: nomination or referential strategy, predication strategy, argumentation strategy, perspectivation strategy, and intensification strategy. He used those discursive strategies to show his power, representing his ideology through his ideological construction.

The findings above showed that from 15 data, nomination strategies consist of 4 data which are in data $1,5,6$, and 8 . Second, predication strategies consist of 3 data, which are in data 3, 4, and 15. The third, the argumentation strategies consist of 1 data, which is in data 14 . The forth, perspectivation strategies consist of 4 data in data $2,7,9,10$, and 11 . Last, the intensification strategies consist of 2 data which are in data 12 and 13.

Based on the findings, the nomination strategy was used to construct himself in-groups or out-groups. Then, predication was used to label himself positively or negatively, deprecatorily or appreciatively. He used argumentation strategy to justify political inclusion or exclusion. Next, he used perspectivation strategy to express involvement and position the speaker's point of view in reporting, description, narration, or quotation. $\mathrm{He}$ used an intensification strategy to intensify or mitigate the illocutionary force of utterances.

This research provides the analysis using the theory of discursive strategies in order to emerge the power representing ideology in Donald Trump's political speech. Of course, the discursive strategy here proposed by Ruth Wodak. Donald Trump showed his power relation to represent his ideology through the statements of his ideological construction.

\section{CONCLUSION}

This study examined the power representing ideology of Donald Trump on his political speech. The use of five discursive strategies used above showed that Donald Trump political speech supported the intended meaning of his declaration from the data analysis. By combining the two critical discourse analysis terms, Trump discursively influences and controls people to follow his ideological construction.

Based on the findings, Donald Trump used five types of discursive strategies to portray his power and ideology so the people would trust him. From the conclusion, the result of this research is useful to discuss the interdisciplinary of political speech to understand power and ideology on critical discourse analysis area. It is suggested for the next researcher to find more 
comprehensive data to investigate power representing ideology in very distinct approaches and different contexts, except politics. Future researchers could investigate power representing ideology in the education context using other theories. These studies would give broad insights to the linguistics field. Moreover, combining two or more theories could result in a new finding.

\section{REFERENCES}

[1] R. Wodak, M. Meyer. Methods of Critical Discourse Analysis. London: SAGE Publications, 2001.

[2] J. L. Martin, "What is Ideology?", SOCIOLOGIA, PROBLEMAS E PRÁTICAS, 772015 9-31, DOI: 10.7458/SPP2015776220

[3] R. Wodak, Politics as Usual: The Discursive Construction and Representation of Politics in Action. London: Palgrave Macmillan, 2009.

[4] H. Popitz (1992). The Discourse-Historical Approach, in Ruth Wodak (Ed), Methods of Critical Discourse Analysis. Ch-04 (p.89). Retrieved November 25, 2018, from https://www.researchgate.net/publication/251636 976 The Discourse-Historical Approach DHA

[5] N. Fairclough, and R. Wodak, "Critical discourse analysis", in T.van Dijk (ed.), Discourse Studies: A Multidisciplinary Introduction. Volume 2. London: Sage, 1997
[6] A. A. Putra, Power Relation on Donald Trump's Political Campaign 2015. Undergraduate thesis, Universitas Islam Negeri Maulana Malik Ibrahim, 2016

[7] F. D. R. Swari, Rhetorical Devices Representing Power Relation for Group Affiliation on 2016 U.S Presidential Debate. Undergraduate thesis, Universitas Islam Negeri Maulana Malik Ibrahim, 2017

[8] Nazla, Ideology Reflected on Persuasive Strategies in Nara Masista Rakhmania's Speech at United Nations General Assembly. Undergraduate thesis, Universitas Islam Negeri Maulana Malik Ibrahim, 2017

[10] A. Holzscheiter, Power of Discourse and Power in Discourse: an Investigation of Transformation and Exclusion in the Global Discourse of Childhood. PhD dissertation, FUerlin, 2005

[11] T.A. Van Dijk, 'Discourse, Knowledge and Ideology', in M. Pütz, J. Neffvan Aertselaer and T. A. van Dijk (eds), Communicating Ideologies. Frankfurt: Peter Lang, 5-38, 2004

[12] M. Riseigl and R. Wodak, 'The DiscourseHistorical Approach', in Ruth Wodak (eds) Methods of CDA. Vol: 1. London: SAGE Publications, 2008. 